\title{
IS ACCOUNTING FOR AGRICULTURAL ASSET APPLICABLE IN INDONESIA?
}

\author{
Dewi Nurul Hasanah Uswati ${ }^{1,2 *}$, Ludigdo Unti ${ }^{3}$, Hariadi Bambang ${ }^{3}$, \\ Prihatiningtias Yeney Widya ${ }^{3}$ \\ ${ }^{1}$ Doctoral Degree Student in Accounting, Faculty of Economics and Business, \\ University of Brawijaya, Indonesia \\ ${ }^{2}$ Accounting Lecturer, STIE Perbanas Surabaya, Indonesia \\ ${ }^{3}$ Faculty of Economics and Business, University of Brawijaya, Indonesia \\ *E-mail: nurul.dewi@student.ub.ac.id
}

\begin{abstract}
The study aimed to discuss underlying reason why the national agricultural industry, dominated by small and middle sector, did not establish a standardized accounting for agricultural assets instead of adopting IASB accounting system. This new standard would become a better fit for the culture and characteristics of the national agricultural sector. The study used critical paradigm because until recently Indonesia has not adopted IAS 41 yet and as the consequence, there was not any document that recorded biological assets of the livestock industry comprehensively. As an agraris country, Indonesia should establish standardized accounting system for agricultural asset. The finding showed that the national agricultural asset was regulated in an accounting standard that had worked effectively since January 1, 2018. This standardized accounting system adopted IAS 41 accounting system. However, IAS 41 only worked for large-scale agricultural industry and did not work as effectively for the small and middle-scale agricultural industry Indonesia had. The major obstacle was to establish fair value, more particularly one for reliable measurement. Establishment and adoption of standardized accounting system should take local culture and wisdom into account. It is expected that the National Standard Establishment Board's idea to adopt IAS 41 does not lead to new capitalism since evidence showed potentials for nepotism between actors of the agricultural industry.
\end{abstract}

\section{KEY WORDS}

Fair value, historical cost, agricultural assets, IAS 41.

The study focuses on the lack of financial accounting standard for the national agricultural asset. As an agraris country, Indonesia has currently implemented "Standar Akuntansi 69," an accounting system adopted from IAS 41 on January 1, 2018 after a twoyear delay. Standardized harmonization is the reason for the adoption of IAS 41 in PSAK 69. Based on study of the Institute of Chartered Accountants of Scotland (published in February 2011), once the system was implemented, IAS 41 had various drawbacks (Aryanto, 2011). Elad (2004) stated that IAS 41 was controversial because it showed the most radical and comprehensible distinction of fair value accounting and thus, caused both theoretical and practical issues. This distinction may be seen in value of company's assets, revenues and profit among others. Elad (2004) also explained that using subjective assesment in fair value estimation, for example similar asset market prices or the use of current value models, would result in different treatments which may inhibit comparability and harmonization. Furthermore, Herbohn and Herbohn (2006) and Dowling and Godfrey (2001) emphasized on increase in volatility, manipulation and subjectivity from reported income based on fair value.

Another purpose of the adoption of IAS 41 into PSAK 69 is standard harmonization. Some studies showed crtiticsm towards standard harmonization that similar accounting standard worked in all countries. Mulawarman (2012) and Rodrigues and Craig (2007) described hegemony of nation through accounting standard. Furthermore, Rodrigues and Craig (2007) revealed that IFRS accounting standard could accommodate interest of listed company only, and therefore, it was suggested that IFRS accommodate that of both listed 
company and small medium enterprises (SME). Furthermore, convergence refers to a process that should take harmonization between industries and environmental sustainability into account. Therefore, plan to adopt IAS 41 completely become paradoxical picture since, based on the data from the Department of Agriculture, the national agricultural industry is dominated by small and middle-scale agricultural industry. Thus, instead of using IAS 41 as the sole basis of PSAK 69, it should take into account recognition, assesment and disclosure of agricultural assets for smaller industry.

The researchers used this rationale to discuss underlying reason why the national agricultural industry, dominated by small and middle sector, did not establish a standardized accounting for agricultural assets instead of adopting IASB accounting system. Previous studies on agricultural assets are dominated by ones discussing crops; very few studies on the sector focused on livestock. Literatures on IAS 41-based agricultural asset mostly discussed crops and plantation, for example Mates and Grosu (2008), Bohušová et al. (2012), Kurniawan et al. (2014), Grege-Staltmane (2010), Jana and Marta (2014), Lefter and Roman (2007), Josep et al. (2009), Sedlacek (2010), Athanasios, Athianos, Strergios (2010), Feleaga et al. (2012), Argilés Bosch et al. (2012), Cooper and Sherer (1984). Very few studies discussed cattle or livestock. This is an interesting phenomenon, since according to IAS 41, agricultural asset involves both plant and also living animal (Lefter and Roman, 2007).

In general, based on the previous elaboration, there are several aspects related to the government's plan to adopt IAS 41 into ED PSAK 69 to criticize and discuss in this study. Elad and Herbohn (2011) conducted study in France, England and Australia. The study revealed interesting fact. Even though IAS 41 is implemented in those countries, but asset recognition with cost model is the most common model used for agricultural asset. The study explained that 9 out of 17 companies in France that were legally required to adopt IAS 41 refuted assumption that reliable assessment of fair value was possible; it justified the use of cost model although various alternatives for fair value were applicable, for instance net present value, independent or external assessment for aprisal, net realizable value, as well as market value. Implementation of these alternatives from one country to another is not similar. Therefore, IAS 41 has failed to improve comparability of accounting practice for agricultural sector in international level. IAS 41 adoption into PSAK 69 that treats all agricultural assets equally, is predicted to result in similar issues. IAS 41 used accretion as treatment for all agricultural assets, creating problem for its implementation in the industry. Based on agricultural industry actors in Malaysia and India, it is a challenge to apply fair value method for biological assets before harvest (AOSSG, 2013). Malaysia Accounting Standard Board (MASB) suggested IASB to develop practical guidance for measuring biological asset before harvest but IASB has not come up with one yet until recently. There is a possible that similar issue will take place once Indonesia adopts IAS 41.

Rodrigues and Craig (2007)'s study revealed that IFRS accounting standard accommodated interest of listed company only, and therefore, IAS 41 may only be implemented in large industry more particularly companies listed in secondary market. How about livestock industry in Indonesia? Data from the Agricultural and Livestock Office showed that until 2013 small and middle-scale industry dominate agricultural commodity in Indonesia (Nurtini and Anggriani, 2014: 10). Adoption of IAS 41 into PSAK 69 allow only very few industries to meet standardized disclosure for agricultural asset. In order to benefit the national agricultural industry, PSAK 69 should take the current condition of the industry into consideration.

\section{METHODS OF RESEARCH}

Critical Paradigm as Reseach Foundation. The study used qualitative design since there was relationship between the theoretical framework and the statement of problem and meaning attached to individual or group in natural social environment. The sources of data were participants, the researchers' intuitive reflection, interpretation and description of the statement of problem as well as review of related literatures. The objective was to make 
interpretation on particular issue without quantitative data analysis (Creswell, 2013:59). Paradigm in social definition was one of the specific aspects of Weber's analysis on social action. There are three theories in the social definition paradigm, namely action theory, symbolic interaktinism, and phenomenology. Herbert Blumer, one of symbolic interactionism experts, stated that human society organization was framework in which individual behavior was not deciding factor of social action.

The study used critical paradigm. This paradigm was used because until recently livestock industry in Indonesia has not adopted IAS 41 yet and therefore, there was not any sufficient record for the industry's agricultural asset. As an agraris country, Indonesia should establish an accounting standard for its agricultural asset.

Research Setting and Unit of Analysis. Preliminary observation was conducted to decide research setting, unit of analysis and informant. Based on the observation, the researchers found out that Indonesia has not established an accounting standard for either livestock or plant. There is a regulation issued by the Ministry of Finance. In addition, most cattlefarms, more specifically cows, are located in Java and most of these cattlefarms are small-scale industry. Culture plays significant role in agricultural industry and assets and as the consequence, IAS 41 adoption was quite a challenge. Based on the phenomenon, the setting of the study was agricultural industry. The unit of analysis was how readers (informants) put meaning towards agricultural asset recording in different scales of agribusiness industry. The informants were agricultural business actors, auditor, and academics.

Purposive sampling was used to select the informants. Criteria for being selected as the informants were individuals who were involved in activities that become the target of this study frequently and for significant amount of time. The informants were able to not only give information but also had comprehension towards the national agricultural industry due to their active participation. Their active participation in this environment or activity was the primary consideration in selecting these individuals as the informants.

Data Collection Technique. The researchers acted as research instrument so that they were able to organize field activities and path of study (Moleong, 2006: 163). The data collection methods were focus group iscussion (FGD), interview, field observation in agricultural industry and documentation.

The interview was conducted in both formal and non-formal setting depending on context of the study in order to obtain data on the informants' perspectives on biological asset assessment. Interview allowed the researchers to have natural interaction with the informants and convey meaning behind the interaction.

The researchers also developed some questions based on the informants' feedback. These feedbacks would convey meaning in an interaction between the actors in biological asset assessment. Meaning was sometimes conveyed during interaction with other people's help instead of random act. Interaction between people held developing meaningful comprehension. Such comprehension, according to Moleong (2006:11), was essential in symbolic interaction. Hence, interaction became conceptual paradigm that exceeded "instrinsic motivation," "personal characteristics," "subconscious motivation," "conincidence," "socio-economic status," "role obligation" or its physical environment. These theoretical concepts may be beneficial but was only relevant once definition process has begun.

Method of Analysis. This study was intended to give interpretation towards reality taking place in agricultural asset assessment using critical perspective. Traditionally, agricultural asset was based on recognition, acquisition, recording, and asset valuation. Agricultural asset became interesting because it was a growing asset. In small-scale cattlefarm, there was an interaction between farmers because cross-breeding where the farmers lended and borrowed livestock between each other was a common phenomenon in the cattlefarm.

The analysis and discussion were continued with understanding meaning of the biological assets assessment through valuation symbols as a phenomenon in livestock business. Methods to understand interaction was through symbols used by individuals in 
performing an action and interaction. The data obtained from the informants were then analyzed using the principles of symbolic interactionism (Ritzer and Goodman, 2013: 373).

\section{RESULTS AND DISCUSSION}

The purpose of this research was to criticize the implementation IAS 41 as the accounting standard for agricultural asset in Indonesia. The data collection techniques were focus group discussion (FGD), observation in the agriculture industry, and interviews with the actors in the industry. Based on the results of the focus group discussions (FGD) involving the National Standard Establishment Board, agricultural industry actors, auditors from public accountant offices and financial accounting lecturers, observation and interview, a standardized accounting system for agricultural assets was necessary because Indonesia as agroindustrial country planned to go towards the industrial revolution 4.0. However, the full adoption of IAS 41 was not a suitable decision because the national agricultural industry was dominated by small and medium-scale industry. IAS 41 was more suitable for listed in the listed company instead of smaller scale industries.

This research attempted to describe the implementation of IAS 41 in various countries in order that Indonesia established a more suitable accounting standard for its agricultural industry and economic structure. Criticism towards the globalization of accounting standards was also supported by the actors actively involved in this industry.

Countries in which IAS 41 is Implemented as Reflection of Agricultural Asset Implementationю Researchers have conducted previous studies on implementation of IAS 41 in several countries. They generally focused on agricultural sector or crops. Malaysia Accounting Standard Boards (MASB) stated that the implementation of IAS 41 in Malaysia encountered various issues and so did in India and other countries. Elad and Herbohn (2011) conducted study on implementation of IAS 41 in UK, France and Australia. Elad and Herbohn (2011) found out that these countries applied IAS 41 on asset recognition using cost model, the most frequently used model for biological asset. The finding revealed 9 out of 17 French companies that were required by law to adopt IAS 41 refuted assumption that reliable measurement of fair value was possible. It justified the use of cost model although various alternatives for fair value were applicable, for instance net present value, independent or external assessment for aprisal, net realizable value, as well as market value. Implementation of these alternatives from one country to another is not similar. In short, IAS 41 failed to increase comparability of accounting practice in agricultural sector in internasional level.

Mates and Grosu (2008) conducted study on IAS 41 adoption in agricultural sector. The study tried to evaluate IAS 41 and stated that this accounting standard regulated accounting treatment as well as information related to biological asset in agricultural activities. Mates and Grosu (2008) postulated that IAS 41 did not discuss how frequent company should conduct biological asset assesment, and therefore, drew conclusion that asset evaluation or estimation should be conducted that at the end of an accounting period although there was not any rules that stated as such. Mates and Grosu (2008) also explained that IAS 41 described general overview on fair value of biological assets that could be realized. IAS 41 was a standard that regulated biological asset management in terms of increase in agricultural harvest, logging, cultivation; horticulture and aquaculture. Biological transformation refers to growing, maturing, production and procreation of biological asset. This transformation may also result in new types of plants or transformation of other biological assets. Relevant characteristics to classify asset are nature, naturalness, possibility for consumption and production quality and capacity.

Various criticismo $\mathrm{n}$ this issue also appeared in Czech Republic. Bohušová et al. (2012) pointed out discrepancy between agricultural activities and activities unit business conducted to maintain going concern through profit-seeking. The study was conducted in Czech Republic. Agricultural activity relied on nature, environment and geographical position. Objective of the study was to identify potential issues IAS 41 might encounter and 
suggestions to eliminate the issues. Bohušová et al. (2012) identified biological asset that specifically analyzed agricultural production up until asset transformation.

Finding of Bohušová et al. (2012)'s study showed similar to Indonesia, Czech Republic once used Generally Accepted Accounting Principal as accounting standard and then IAS based on FASB suggestion with IFRS standard. Bohušová et al. (2012) revelaed that implementation of IAS 41, more particularly in terms of reporting, was quite sophisticated. IAS 41 did not provide any solution for transformed asset reporting. Cost model was considered more relevant for agricultural sector compared to fair value making implementation of IAS 41 in Czech Republic heavily influenced by cost method, the foundation of GAAP. Bohušová et al. (2012) also questioned what method non public accountability industry that applied IAS 41 should take in terms of reporting; in other words, IAS 41 was suitable for large-scale industry listing in secondary market only.

Kurniawan et al. (2014) also conducted study on IAS adoption plan in Indonesia. Kurniawan et al. (2014) conducted a study in plantation sector and in-depth meaning dimension. It aimed at anticipating threat that may appear in biological asset assessment due to monetary logocentrism in accounting. It offered a new concept that adopted Indonesian culture developed based on ethnomethodology from Indonesian farmers' point-of-view as well as lives that were closely related to agricultural utility cycle. The study showed that agricultural accounting was applicable even though another approach but monetary unit was used as valuation.

Grege-Staltmane (2010) conducted study on IAS 41 in Latvia. The study focused on forest accounting because of the researcher's assumption that forest had longer production cycle. Thus, forest accounting had distinctive characteristics. The researcher argued that accounting experts paid very little attention on accounting for forest activity. This article analyzed IAS 41 application for forest accounting using fair value as foundation. The finding showed that land and log of wood value should be recorded separately and one should predict fair value of growing piece of wood. The researcher mentioned that despite of the International Accounting Standard Board (IASB)'s effort for improving biological asset accounting using IAS 41, forest accounting still needed some improvement.

Jana and Marta (2014) also conducted study on biological asset and agricultural harvest evaluation process based on IAS 41. Objective of this study was to describe how much influence IAS 41 implementation had towards business actors' behavior. The finding became suggestion for Exposure Draft ED/ 2013/8 to compare between the findings and solution stated in Bearer Biological Asset (BBA) (IAS 16 and IAS 41 Proposed Amendment), the International Accounting Standard Board (IASB) published for the comment accepted on October 28, 2013. The researchers distributed questionnaire to 104 agricultural companies and then compared the questionnaires to solution IASB proposed. Objective of this study was to verify the following hypotheses: opinion of most respondents who filled out the questionnaire on how to use biological asset assessment value and agricultural harvest and whether or not it was conflicting to the solution when ED was adopted.

IAS 41 was considered as important standard because it was starting point for consistent transition from Historical Cost $(\mathrm{HC})$ principle to fair value (FV) accounting (Lefter and Roman, 2007). Besides that, this economic branch play significant role for developing countries. On the other side, 41 was also applicable for agricultural activities of companies from other sectors. Josep et al. (2009) who conducted another study on agricultural asset did not find any significant difference between fair value (FV) and historical cost (HC) in terms of biological asset revenue volatility recording. There was not any different in terms of profitability, earnings management, and cash-flow predictability in agricultural sector either. However, hypothesis-testing showed FV had higher predictive ability for future profit. The study also provided evidence on $\mathrm{HC}$ accounting practice in agricultural sector and concluded that FV was interesting instrument for agricultural sector in European Union. Another study on biological asset assessment and agricultural production was one conducted by Sedlacek (2010). The study analyzed implementation of the assessment in two dimensions, one taking place in Czech Republic and internationally. The researcher then analyzed the comparison and its influence towards financial report as well as differences in fair value implementation. 
Athanasios, Athianos and Ekaterini (2010) conducted a study on discrepancy between accounting practice and role of accounting information in agricultural sector. The study showed that the gap caused by accounting regulation that did not represent agricultural characteristics, need for agricultural management, sustainable development in rural areas. The finding showd that after required and voluntary adoption for public company, small and middle-scale business in European Union in 2005, the researchers concluded that the main contribution of IAS 41 was to provide strong conceptual working framework in agricultural accounting practice.

Conducting a study in Romania, Feleagă et al. (2012) stated that even though agriculture was essential part of economic world, agricultural accounting had some drawbacks. IAS 41 adoption for agriculture had attempted to overcome this situation and improve comparability of financial report entity in agricultural sector. Although controversial, IAS 41 was the first step for consistent transition for fair value assessment in agricultural sector. Objective of this study was to compare between IAS 41 and agricultural accounting practice in Romania. Accounting regulation in Romania followed European accounting regulation that used IFRS referential, even though Romania had never mentioned explicitly that the country adopted IAS 41.

'McDonalization' Versus Glocalization of Accounting Standard for Agricultural Asset. There is possibility that Indonesia will encounter similar issue as other countries that adopt IAS 41. Financial accounting standard is developed to maintain consistency in financial reporting. Accounting standard that works in general allows entity to make uniformed financial report that interest group understands. When every company has its own accounting standard, it will be difficult to understand financial report from other companies. However, it does not mean that accounting standard puts aside current condition, culture and growth of local industry of a country where it is applied. As the result, McDonalization in accounting standard appears.

Ritzer (1993: 567) described McDonaldization as a society or culture who shares the same principle as McDonald, the fast-food restaurant. In McDonald, every thing was done instantly. McDonaldization society refers to society whose thinking process has shifted from traditional to rationale or modern and who emphasizes on time efficiency. This society wants to get maximum result in the least amount of time and using the least amount of energy. Ritzer (1993) identified four dimensions of McDonaldization, namely McDonald offered efficiency (quick service), predictability (no surprise) or nett price, calculating ability (fast and affordable), and control using non-human technology for its operating system (controlling both employee and customer). People are attracted to, fall in love and develop in the four components that become foundation of the rational system.

Efficiency means to select optimum instrument for final outcome that has been established previously. In this context, optimum refers to effort to access and use available facility as effectively as possible. The definition is not general description that public will understand; instead, in McDonalized society, it is impossible to trace one best instrument to achieve the final outcome. This society tends to depend upon established and institutionalized society. In other words, they are guided to have "more efficient interest." In reality, efficiency may refer to process, product simplification and technical activities/ service that require customers to do exactly the same thing as service provider. In terms of process, McDonaldized organization will prepare efficient working procedure and production technic that involve a group of employee with certain tasks and modern technology.

In 'calculation; context, McDonaldization emphasizes on calculable and countable item as well as quantity over quality. Emphasis on quantity is related to process or final outcome. Process emphasizes on speed while final outcome focuses on result of production and number of serving. It is expected that this dimension will result in efficiency because a welldesigned, calculable element will support principle of efficiency.

Calculable dimension emphasizes on product quantity over quality followed by creating illusion about quantity for customer and maintaining production and service into controllable number. To create the illusion, product is presented as such in order to "look excessive" while production and service focus on measuring every element of input prior to production in 
order to control both quality and quantity. Speed is another important element of this principle. McDonaldized organizations will try to create breakthrough that allows them to produce and serve as many products in relatively short amount of time.

The following dimension is predicting principle. McDonaldization provides predictability in many aspects for employee, organization and customer. This principle allows employee to get information on job description. For organization, product predictability in several aspects will get easier because of uniformed process. At last, control lies upon shift from human to non-human technology through methods to increase control over production, employee and customer. Technology in this context is related to not only machinery and equipment but also material, skill, knowledge, law, regulation, procedure and technique. Technology is designed to eliminate human-error. This dimension puts more emphasis on negative impact of McDonaldization. Rational principle that becomes working principle of modern organization in McDonaldization eventually results in irrationality, for example inefficiency, inability to make prediction or making calculation, loss of control and more importantly eliminating principle of humanity.

McDonalization is also evident in Indonesian accounting standard. Pressure from G-20 countries forced Indonesia to develop harmonious and global accounting standard, which work for listed companies only. The study does not put aside importance of globalization and borderless business as impact of globalization. Business actors favor multinational companies and one standardized accounting standard that works across the globe will make international business a lot easier. Implementation of certain accounting standard such as PSAK 1, which adopted IAS 1 on financial reporting, PSAK 53 on share-based payment, PSAK 50, PSAK 55, and PSAK 60 on financial instrumentation will make more sense. It is nearly impossible to develop accounting standard that is not suitable with business trends in globalization era. However, IAS adoption into ED PSAK 69 is not a suitable concept for Indonesian setting because the country's socio-cultural and agricultural aspects are different from those of other countries. PSAK 69 should take into account measurement for decreasing asset value since PSAK 48 discusses decrease of fixed asset value only.

Indonesia has IFRS-based accounting standards for commercial business called Standar Akuntansi Keuangan Entitas Tanpa Akuntabilitas Publik (SAK-ETAP) and Standar Akuntansi Keuangan Entitas Menengah Kecil dan Mikro (SAK EMKM), which is still in exposure draft stare for commercial business. These work effectively in January 1, 2018. However, IFRS-based SAK got most of the government's attention. The National Standard Establishment Board has put to much emphasis on development of IAS since 2009 and as the consequence, it took the board two more years to establish SAK ETAP in January 1, 2011. The board has never evaluated how beneficial and reliable SAK ETAP is until recently. It is evident from numerous irrelevant terminologies in SAK ETAP, for example IFRS-based PSAK 1 SAK is using the term Statement of Financial Position instead of balance sheet whereas SAK ETAP is still using the terminology.

Due to efficiency, calculability, predictability and control dimension, the National Standard Establishment Board adopted IFRS that can work effectively for large-scale industry only. Several industries that do not have public accountability are forced to apply IFRS-based SAK even though de jure they do not have responsibility to do so since SAK ETAP that stereotypically is designed for SMEs does not have interesting make up.

Improvement should me made for SAK ETAP and SAK EMKAM so that these standards provide more benefits for agricultural industry, such as for agricultural asset. The government should encourage agricultural SMEs, which do not have public accountability, to develop standard that meet social, political and cultural condition in Indonesia. The National Standard Establishment Board should shift their focus from adopting IAS 41 into PSAK 69 to develop accounting standard that is more suitable for the national agricultural asset.

Criticsm towards IAS 41 adoption into PSAK 69 for agricultural asset will be directed towards glocalization of accounting standard. Glocalization refers to concept about individual, group, organization, product or service that represents both global and local standard. Roland Robetson, a sociologist, is the first person who coined the term glocalization. This terminology is a combination between "globalization" and "localization." It is adopted from a 
Japanese terminology dochakuka, which means adapting local context into farming technique. In other words, Japanese uses the term as marketing strategy to sell product that meets market expectation. Glocalization is frequently used since Roland Robetson made it popular in 1980.

In short, glocalization is using local value for interpretation of global value. Important elements of glocalization are first, the world is developing into a more pluralistic direction, second, local individual and group have tremendeous ability to adapt, make innovation and maneuver in the world where glocalization takes place, third, all social process are related to and depend on one another and four, commodity and media are not coercive or forceful social control; instead it provides material for individual or group creation when glocalization occurs.

Glocalization is the impact of globalization. Local value is inserted into Western trends in order to make trends more acceptable in non Western countries resulting in acculturation. Therefore, assumption that globalization results in similar culture across the world is not accurate. Globalization brings new set of culture to certain setting and combines it to local value. Globalization has different impacts to each setting because each setting has different local value.

Establishment of McDonald's across the globe is example of globalization but adjusting the fast food menu to attract local customer is an example of glocalization. Glocalization may also mean making a change to global product to meet local customer's demand. This is an alternative phenomenon for americanization. Another more illustrative example of glocalization is McDonald's decision to change its mascot from Ronald McDonald to Asterix, a popular French cartoon character in France. As an addition, the fast-food restaurant has Bulgogi and Kimchi Burger to attract their Korean customers.

The finding of this study showed accounting standard globalization through establishment of accounting standard generic to national agricultural sector, more particularly livestock. Based on IAS 41's biological asset recognition, company can acknowledge its biological asset if, and only if: company controls the assets as result of past transaction; company gets economic benefit in the future; and the asset has fair value or reliable measurement for asset cost. Due to its distinctive characteristics, biological asset measurement is conducred using several approaches.

Biological transformation will change value of a biological asset. Having compared several approaches, fair value is the most frequent approach for biological asset measurement and therefore, becomes IFRS standardized biological asset measurement. In IFRS, IAS 41 consists of statement on biological asset measurement. Based on IAS 41, biological asset is measured based on its fair value. Biological asset is measured during the first recognition and on the following date of fair value subtracted by its estimated market price, unless reliable fair value measurement is not possible. Fair value of biological asset is obtained based on its price in active market. Active market refers to market in which item is traded in homogenous method, seller and buyer meet under normal circumstances and affordable price. Cost of sale includes commission for intermediaries or distributor appointed by the authority, as well as trnasferrable tax or fee. Transportation fee and fee to transport item into the market are not involved in this type of cost.

Market price in active market for biological asset or harvest is the most reliable foundation to decide fair value of an asset. When active market is not accessible, there are several other methods to determine fair value of biological asset, namely: market price from current transaction, which does not have significant price difference between price during the transaction and price at the end of period or when biological asset measurement is conducted, or market price of a similar item after making some adjustment if there is any difference between price of these two.

Mutual Relationship in Agricultural Industry. Farmers who own small and middle-scale agricultural business are accustomed of helping each other. During breeding time, a farmer may borrow bucks (male goats) from other farmers and then they would share the kids (young goats). Another farmer stated that they did not bread cows that produce milk. 
Farmers had certain bulls (male cow) and cows (female adult cow) for breeding. When they did not have one, they would make certain agreement with other farmers.

Based on the informants' responses, implementation of IAS 41 for biological asset (dairy cows) record was quite a challenge. Based on IAS 41, biological asset was measured based on the fair value. Biological asset assessment should be conducted in the first recognition and the following recognition on fair value subtracted by an estimated market price, unless reliable measurement of fair value was not possible.

\section{CONCLUSION}

Biological asset is a type of asset that mostly used in agricultural activities. Agricultural activity is a process to transform biological assets into processed goods for consumption. Biological transformation is the main characteristic of biological asset. Biological transformation includes growing, degeneration, production and procreation which is caused by qualitative and quantitative change in living being and results in agricultural products or additional biological assets with the same type.

Standardized accounting for agricultural asset worked effectively starting from January 1, 2018. This standardized accounting system adopted IAS 41 accounting system. However, IAS 41 works effectively in large-scale industry only while the national agricultural sector is dominated by small and middle-scale industry. The major obstacle is to apply fair value, more particularly in reliable measurement. Culture and local wisdom are two elements one should take into account in developing or adopting accounting standard. It is expected that the National Standard Establishment Board's idea to adopt IAS 41 does not lead to new capitalism since evidence showed potentials for nepotism between actors of the agricultural industry.

The limitation of the study is that it only involves agricultural industry actors as the informants. The researchers do not involve other agricultural industry actors such as horse breeder. Agricultural assets the horse breeder has are observed based on the breeding process instead of the outcome.

Future researchers should conduct a study focusing on implementation of accounting standard for agricultural asset in agricultural sectors. Considering the fact that this study was conducted at the time PSAK 69 has just been implemented for a few months, the informants have tendency to voice their concern on whether or not they are able to apply the standard successfully.

\section{REFERENCES}

1. Argilés, B. J. M., Aliberch, A. S., \& Blandón, J. G. (2012). A comparative study of difficulties in accounting preparation and judgement in agriculture using fair value and historical cost for biological assets valuation. Revista de Contabilidad, 15(1), 109-142.

2. Aryanto, Y. H. (2011). Theoretical failure of IAS 41. Retrieved from SSRN: https://ssrn.com/ abstract=1808413.

3. Athanasios, V., Athianos, S., \& Ekaterini C. L. (2010). The importance of information through accounting practice in agricultural sector-European Data Network. Journal of Social Sciences, 6(2), 221-228.

4. Bourdieu, P. (2005). The social structures of the economy. UK: Polity Press.

5. Bohušová, H., Svoboda, P., \& Nerudová, D. (2012). Biological assets reporting: is the increase in value caused by the biological transformation revenue? Agric. Econ. Czech, 11(11), 520-532.

6. Bryer, R. A. (1999). Marx and accounting. Critical Perspectives on Accounting, 10(5), 683-700.

7. Bryer, R. A. (2006). The genesis of the capitalist farmer: towards a Marxist accounting history of the origins of the English agricultural revolution. Critical Perspectives on Accounting, 17(4), 367-397.

8. Cooper, D.J., \& Sherer, M.J. (1984). The value of corporate accounting reports: 
Arguments for a political economy of accounting. Accounting, Organizations and Society, 9(3-4), 207-232.

9. Denzin, N. K. (1989). Interpretive Interactionism, Applied Social Research Methods Series. London: Sage Publication.

10. Denzin, N. K., \& Lincoln, Y. S. (2005). The SAGE Handbook of qualitative research Third Edition. USA: SAGE Publication, Inc.

11. Dowling, C., \& Godfrey, J. (2011). AASB 1037 sows the seeds of change: a survey of SGARA measurement methods. Australian Accounting Review, 11(1), 45-51.

12. Elad, C., \& Kathleen, H. (2011). Implementing fair value in the agricultural sector. The Scottish Accountncy Trust for Eduction and Research.The Institute of Chartered Accountants of Scotland. UK: T. J. International Ltd.

13. Elad, C. (2004). Fair value accounting in the agricultural sector: some implication from the international accounting harmonization. European Accounting Review, 13(4), 621641.

14. Feleagă, L., Feleagă, N., \& Răileanu, V. (2012). Theoretical considerations about implementation of IAS 41 in Romania. Theoretical and Applied Economics, 19(2), 31-38.

15. Grege-Staltmane, E. (2010). Challenges in accounting the forests - a Latvian case study. Annals of Forest Research, 53(1), 51-58.

16. Gray, S. J. (1988). Towards a theory of cultural influence on the development of accounting systems internationally. Abacus, 24(1), 1-15.

17. Herborhn, K., \& Herbohn, J. (2006). International Accounting Standard (IAS) 41: what are the implications for reporting forest assets?. Small-scale Forest Economics, Management and Policy, 5(2), 175-189.

18. Jana, H. (2014). The fair value model for the measurement of biological assets and agricultural produce in the Czech Republic. Procedia Economics, 12(3), 213-220.

19. Josep, M. A., Blandon, J. G., \& Monllau, T., (2009). Fair value and historical cost accounting of biological assets. Working Papers in Economics, 1-15.

20. Kurniawan, R., Mulawarman, A. D., \& Kamayanti, A. (2014). Biological assets valuation reconstruction: a critical study of ias 41 on agricultural accounting in indonesian farmers. Procedia - Social and Behavioral Sciences, 164(8), 68-75.

21. Lefter, V., \& Roman, A. G. (2007). IAS 41 agriculture: fair value accounting. Theoretical and Applied Economics, 5: 12-15.

22. Lutfi, A. N. (2010). Pemikiran agraria bulaksumur: telaah awal atas pemikiran Sartono Kartodiharjo, Masri Singaribun, Mubyarto. Yogyakarta: Sajogo Institute STPN Press.

23. Mates, D. (2008). Evaluating and recognizing biological assets and agricultural activities according to IAS 41. Lucrări Ştiinţifice, seria Agronomie, 51: 457-462.

24. McGee, P. F., \& Bandyopadhyay, J. (2009). A contribution to practice: exploring the curriculum impact of IFRS-US GAAP convergence. Competition Forum, 7(2), 496-504.

25. McQuail, D. (2011). Teori Komunikasi Massa (6th Ed). Jakarta: Salemba Humanika.

26. Mulawarman, A. D. (2012). Akuntansi syariah di pusaran kegilaan IFRS-IPSAS neoliberal: kritik atas IAS 41 and IPSAS 27 mengenai pertanian. The Seminar Internasional 6th Hasanuddin Accounting Days, Universitas Hasanuddin Makasar.

27. Neuman, W. L. (2011). Social Research Methods: Qualitative And Quantitative Approaches (7th Ed). UK: Pearson International.

28. Nurtini, S., \& Anggriani, M. (2014). Profil Peternkan Sapi Perah Rakyat di Indonesia. Yogyakarta: Gadjah Mada University Press.

29. Rodgigues, L.L. (2007). Assesing international accounting harmonization using Hegelian dialectic, isomorphism and Foucault. Critical Perspectives on Accounting, 18(6), 739-757.

30. Ritzer, G. (1993). The McDonaldization of Society: An Investigation Into The Changing. California: Pine Forge Press Newbury Park.

31. Scott, W. R. (2009). Financial Accounting Theory. Canada: Prentice-Hall Canada Inc.

32. Sedlacek, J. (2010). The methods of valuation in agricultural accounting. Agricultural Economics-Zemedelska Ekonomika, 56(2), 59-66.

33. Stigler, G. J. (1971). The theory of economic regulation. Bell Journal of Economics and Management Science, 2(1), 3-21. 